\title{
SENSITIVITAS DAN SPESIFISITAS MEDIA KROMOGENIK SEBAGAI DETEKSI DINI ESCHERICHIA COLI DAN KLEBSIELLA PNEUMONIAE PENGHASIL EXTENDED SPECTRUM BETA LACTAMASE (ESBL) DARI SPESIMEN URIN PASIEN DI RSUD DR. SOETOMO SURABAYA
}

\author{
Cut Asmaul Husna ${ }^{*}$ \\ ${ }^{1}$ Bagian Mikrobiologi Fakultas Kedokteran, Universitas Malikussaleh, \\ Jl. H. Meunasah, Uteunkot, Cunda, Lhokseumawe, Provinsi Aceh, 24351 \\ *Corresponding Author: cutasmaulhusnadr@yahoo.co.id
}

\begin{abstract}
Abstrak
Infeksi nosokomial yang disebabkan oleh bakteri resisten antibiotik termasuk bakteri penghasil ESBL telah banyak dilaporkan di seluruh dunia. Enzim ESBL paling banyak dihasilkan oleh Enterobacteriaceae, terutama Escherichia coli dan Klebsiella pneumoniae. Medium kromogenik merupakan suatu medium generasi baru sebagai metode kultur secara cepat yang menggabungkan antara deteksi presumtif ESBL dengan identifikasi organisme, yang dapat dijadikan sebagai salah satu skrining. Tujuan penelitian ini adalah untuk menganalisis sensitivitas dan spesifisitas medium kromogenik sebagai deteksi dini Escherichia coli dan Klebsiella pneumoniae penghasil ESBL dari spesimen urin. Penelitian merupakan uji validitas diagnostik. Terdapat 343 spesimen urin yang berasal dari ruangan anak, penyakit dalam dan bedah, semua urin diinokulasikan ke medium kromogenik, disamping pemeriksaan rutin dengan Mac Conkey Agar (MCA) dan Blood Agar (BA). Hasil yang tumbuh pada medium kromogenik diidentifikasi sebanyak 98 sampel berdasarkan warna koloni, 41 sampel menghasilkan koloni berwarna merah dan 28 sampel koloni berwarna hijau, sisanya tumbuh dengan koloni yang tidak berwarna. Terdapat 146 sampel yang tumbuh pada MCA dan BA yang selanjutnya diidentifikasi ddengan Phoenix sebagai gold standard, 32 sampel E. coli dan 18 sampel K. pneumoniae dengan ESBL. Hasil ini dibandingkan untuk menilai sensitivitas dan spesifisitas. Analisis data menggunakan Mc Nemar dan uji Kappa, dengan hasil $(\mathrm{P}>0,05)$ yang menunjukkan tidak terdapat perbedaan yang signifikan antara medium kromogenik dengan Phoenix dalam identifikasi E. coli dan K. pneumoniae penghasil ESBL. Didapatkan sensitivitas, spesifisitas, PPV masing-masing untuk E. coli adalah 96,9\%, 80\% dan 91,2\%; 100\% untuk K. pneumoniae. Hasil deteksi dan identifikasi E. coli dan K. pneumonia penghasil ESBL yang dibandingkan dengan Phoenix menunjukkan perbedaan $\mathrm{P}>\mathrm{a}$ dengan sensitivitas $98 \%$, spesifisitas $85 \%$ dan PPV 94,2\%. Kesimpulan penelitian ini menunjukkan bahwa medium kromogenik dapat digunakan sebagai deteksi dini dan identifikasi E. coli dan K. pneumonia sebagai penghasil ESBL pada spesimen urin. Penggunaan medium kromogenik dalam identifikasi E. coli dan K. pneumoniae
\end{abstract}


secara langsung pada spesimen urin menunjukkan sensitivitas dan spesifisitas lebih tinggi pada K. pneumonia dibandingkan E. coli penghasil ESBL.

Kata Kunci : E. coli; K. pneumonia; ESBL; Medium kromogenik; Phoenix; sensitivitas dan spesifisitas; spesimen urin

\title{
SENSITIVITY AND SPECIFICITY OF A CHROMOGENIC MEDIA AS EARLY DETECTION OF EXTENDED SPECTRUM BETA LACTAMASE (ESBL) PRODUCING ESCHERICHIA COLI AND KLEBSIELLA PNEUMONIAE FROM URINE SPECIMEN AT DR. SOETOMO HOSPITAL, SURABAYA
}

\begin{abstract}
Nosocomial infection caused by antibiotic resistent bacteria, include ESBL had been reported around the world. Extended Spectrum $\beta$ Lactamse most found in Enterobacteriaceae, esspecially Escherichia coli and Klebsiella pneumoniae. Chromogenic medium is a new generation medium as early culture that combine between presumtif detection of ESBL with identification of organism, that can used as screening. The research purpose was to analyze the sensitivity and specificity of chromogenic media as the early detection and identification of ESBL producing $E$. coli and K. pneumoniae from urine specimen. The research was the validity of a diagnostic test. There were 343 urine specimen from pediatry, internal medicine and surgery, all urine was inoculated on chromogenic medium, besides routine examination (MCA and BA). The results that grown on chromogenic medium identified 98 samples based on colony color, 41 samples was produced red colony and 28 samples ESBL produces green colony, others produces colorless colony; on MCA and BA 146 samples were subsequently identified with the Phoenix as gold standard, 32 samples E. coli and 18 samples ESBL-producing K.pneumoniae. The results were compared to count sensitivity and specificity, then the data were analyzed using Mc Nemar and Kappa test, result $(\mathrm{P}>0.05)$ that there was not found any significant difference between a chromogenic medium with Phoenix on identification ESBL producing E. coli and K. pneumoniae, there are sensitivity, specificity and PPV respectively for E. coli was $96.9 \%, 80 \%$ and $91,2 \% ; 100 \%$ for K. pneumoniae. The results of the detection and identification of ESBL-producing $E$. coli and K. pneumoniae were compared with the Phoenix showed a difference in results P>a with sensitivity $98 \%$, specificity $85 \%$ and PPV $94,2 \%$. The conclusion of this research was that the chromogenic medium can be used as the early detection and identification of ESBL-producing E. coli and K. pneumoniae in the urine specimen. The use of chromogenic medium in the identification of E. coli and K. pneumoniae directly on urine specimens showed sensitivity and specificity were higher in K. pneumoniae than E. coli.
\end{abstract}

Keyword: E. coli; K. pneumonia; ESBL; Chromogenic medium; urine specimens; Phoenix; sensitivity and specificity 


\section{Pendahuluan}

Salah satu penyebab adanya resistensi mikroba terhadap antibiotik adalah enzim Extended-spectrum beta-lactamase (ESBL). Infeksi nosokomial yang disebabkan oleh bakteri penghasil ESBL telah banyak dilaporkan di seluruh dunia. Extendedspectrum beta-lactamase (ESBL) adalah enzim yang dapat menghidrolisis sefalosporin spektrum luas dan monobaktam, termasuk oximino-cephalosporins (contohnya, seftazidim, sefotaksim, dan seftriakson), tetapi tidak terhadap sefamisin dan karbapenem, dan dapat dihambat oleh asam klavulanat (Bradford, 2001). Sejak pertama kali isolat ditemukan hingga sekarang, angka kejadian infeksi oleh bakteri penghasil ESBL semakin meningkat di seluruh dunia. Gen pengkode ESBL pada bakteri paling banyak berada di plasmid yang memudahkan transmisi ESBL ke bakteri lain, sehingga penyebaran resistensi sangat mudah terjadi antar strain bahkan antarspesies (Paterson dan Bonomo, 2005). Enzim ESBL paling banyak dihasilkan oleh Enterobacteriaceae, terutama Escherichia coli dan Klebsiella pneumoniae (Colodner, 2005). Di negara-negara Asia, kejadian ESBL yang diproduksi oleh E. coli dan K. pneumoniae bervariasi, di Korea 4,8\%, Taiwan 8,5\% dan Hongkong 12\% (Tsang, et al., 2000). Hasil penelitian Antimicrobial Resistance in Indonesia: prevalence and prevention (AMRIN) menemukan bahwa kejadian ESBL cukup tinggi yakni $29 \%$ pada E. coli dan $36 \%$ pada K. pneumoniae (Kuntaman, et al., 2005). Penelitian multicenter dari RSUD Dr. Soetomo (Surabaya), RSUD Dr. Kariadi (Semarang), dan RSUD Dr. Saiful Anwar (Malang) menunjukkan jumlah ESBL positif terbanyak ditemukan pada spesimen urin, dengan jumlah penghasil ESBL terbanyak berasal dari spesies Klebsiella pneumoniae (47.3\%) dan E. coli (42.7\%) (Kuntaman, et al., 2011).
Infeksi yang disebabkan oleh ESBL dikaitkan dengan peningkatan jumlah morbiditas, dan biaya pelayanan kesehatan (Roberts et al., 2009; Schwaber, 2007). Infeksi akibat bakteri penghasil ESBL terus menjadi masalah serius karena tingkat mortalitas yang tinggi, dan sulitnya terapi. Kegagalan dalam mendeteksi resistensi yang diperantarai oleh ESBL telah menyebabkan kegagalan terapi dan berkontribusi pada penyebaran organisme penghasil ESBL yang tidak terkontrol. Sebaliknya, deteksi laboratorium pada pasien yang terinfeksi atau terkolonisasi dengan organisme penghasil ESBL melalui surveilans kultur berguna dalam mengontrol dan mengakhiri wabah nosokomial (Glupczynski, et al., 2006). Penggunaan kultur surveilans atau target skrining terhadap penghasil ESBL pada pasien dengan resiko tinggi atau pada unit yang beresiko tinggi seperti intensive care units (ICU) telah disarankan untuk mencegah atau mengontrol wabah infeksi nosokomial yang diakibatkan oleh mikroorganisme ini (Lucet, et al., 1999 ; Meyer et al., 2009).

Metode deteksi ESBL secara umum dapat digolongkan ke dalam dua kelompok : metode fenotipik dengan menggunakan teknik non molekular, yang memiliki kemampuan deteksi enzim ESBL dalam menghidrolisis berbagai sefalosporin yang berbeda ; sedangkan metode genotipik menggunakan teknik molekular yang dapat mendeteksi gen yang bertanggungjawab dalam memproduksi ESBL. Pada laboratorium diagnostik klinik yang paling banyak digunakan adalah metode fenotipik karena lebih mudah, biaya lebih murah, serta telah banyak digabungkan dengan sistem uji kepekaan otomatis, sehingga lebih mudah digunakan secara luas (Pitout dan Laupland, 2008).

Medium kromogenik merupakan suatu medium generasi baru sebagai metode kultur secara cepat yang menggabungkan antara deteksi presumtif ESBL dengan 
identifikasi organisme. Medium ini menggabungkan substrat kromogenik yang terbentuk sebagai pendeteksi warna pada koloni bakteri dengan cara hidrolisis oleh enzim bakteri yang ditargetkan, sehingga memudahkan dalam membedakan patogen potensial dengan flora lainnya (Gazin., et al., 2012). Selektifitas medium kromogenik dengan adanya campuran antibiotik dan identifikasi presumtif berdasarkan pada warna koloni memungkinkan medium ini untuk digunakan sebagai pemeriksaan skrining yang cepat dan akurat terhadap patogen resisten spesifik pada sampel klinis, terutama untuk skrining karier ESBL yang berperan penting dalam tujuan pengendalian infeksi nosokomial di rumah sakit (Huang, et al., 2010). Penelitian Poupet, et al., (2008) menunjukkan bahwa media kromogenik merupakan media kultur yang reliable dan dapat digunakan sebagai media skrining dan identifikasi presumtif dari Enterobactericeae penghasil ESBL secara langsung dari sampel klinis, seperti feses, urin, pus maupun swab tenggorok. Penelitian lain menunjukkan bahwa medium kromogenik memiliki spesifisitas yang lebih rendah, sehingga dibutuhkan metode konfirmasi lain dalam penegakan diagnosis (Overdevest, et al., 2010).

Koloni penghasil ESBL memberikan warna yang spesifik berdasarkan spesiesnya (E. coli menunjukkan warna pink sampai burgundy; Klebsiella spp., Enterobacter spp., Serratia spp., dan Citrobacter spp. (KESC) menunjukkan warna hijau sampai kebiruan ; sedangkan untuk Proteus spp., Providencia spp., dan Morganella spp. menunjukkan warna orange sampai coklat pada medium kromogenik ESBL. Mikroorganisme NonESBL dapat tumbuh tanpa warna atau bahkan tidak dapat tumbuh sama sekali pada medium kromogenik (Farber, et al., 2008).

Medium kromogenik dapat bermanfaat dalam deteksi dini pada kondisi terjadinya wabah, skrining pasien yang akan dipindahkan ke rumah sakit lain yang secara umum memiliki insiden ESBL yang tinggi, juga untuk memonitor status carrier ESBL pada pasien (Farber, et al., 2008). Penggunaan medium kromogenik yang mudah diharapkan dapat menjadi solusi dalam skrining ESBL khususnya pada laboratorium di Rumah Sakit dengan prevalensi kasus yang tinggi.

\section{Metode}

Jenis penelitian yang dilakukan adalah uji validitas diagnostik. Sampel penelitian adalah spesimen urin yang terkumpul di laboratorium Mikrobiologi klinis yang diperoleh dari pasien rawat inap pada ruangan dengan resiko tinggi insiden ESBL (ruangan anak, bedah dan penyakit dalam) di Rumah Sakit Umum Dr. Soetomo, Surabaya. Sampel diambil secara tehnik consecutive sampling. Sampel yang diambil adalah sampel dengan hasil identifikasi sebagai E. coli dan K. pneumoniae.

Penelitian ini dilakukan di Laboratorium Mikrobiologi Klinis Rumah Sakit Umum Dr. Soetomo, Surabaya. Penelitian ini dilakukan pada bulan Mei Juni 2014.

Pengambilan sampel urin dilakukan oleh petugas rumah sakit yang dilakukan rutin setiap hari. Urin dikumpulkan dari setiap ruangan di RSUD Dr. Soetomo Surabaya. Urin yang diambil dapat berupa urin midstream, urin dari kateter (pada penderita dengan pemasangan kateter), maupun punksi suprapubik (pada kasuskasus tertentu). Urin yang terkumpul dimasukkan kedalam wadah kemudian dikirim segera ke bagian mikrobiologi klinik untuk dilakukan pemeriksaan. Selanjutnya dipilih urin dari ruangan dengan insiden tinggi ESBL seperti urin dari ruangan anak, penyakit dalam dan bedah.

Sampel urin ditempatkan dalam wadah steril, di vorteks, kemudian diambil dengan menggunakan ose yang dicelupkan ke 
wadah urin tersebut. Selanjutnya dilakukan inokulasi pada medium kromogenik, kemudian diinkubasi selama 24 jam pada suhu $35-37{ }^{\circ} \mathrm{C}$. Selanjutnya dilihat hasil koloni yang tumbuh. Perbedaan warna koloni dapat digunakan untuk mengidentifikasi spesies E. coli dan $K$. pneumoniae penghasil ESBL.

Sampel urin yang telah divorteks ditanam pada media Blood Agar (BA) dan Mac Conkey Agar (MCA), pertumbuhan bakteri pada media tersebut setelah 24 jam kemudian diperiksa dengan mesin otomatis Phoenix yang rutin digunakan di RSUD Dr. Soetomo dalam mendeteksi ESBL. Mesin otomatis Phoenix ini menggunakan sistem yang dikenal sebagai BD Phoenix, untuk mendeteksi bakteri penghasil ESBL. Dilakukan pengujian strain, identifikasi dan uji kepekaan terhadap antimikroba, dengan NMIC/ID-50 dan NMIC/ID-70 BD Phoenix GN Combo panels. Dalam mendeteksi ESBL, terdapat perbedaan profil sefalosporin dan kisaran MICs, karena dengan adanya perbedaan ini, diversitas perangkat dari sistem BDXpert diaplikasikan. Panel diinokulasikan dan diinkubasi berdasarkan petunjuk penggunaan. Hasilnya kemudian dianalisis berintegrasi dengan sistem BDXpert.

Hasil spesies E. coli dan K. pneumoniae yang diidentifikasi pada Phoenix kemudian dihitung totalnya dan jumlah penghasil ESBL. Hasil tersebut selanjutnya dibandingkan dengan warna koloni yang dihasilkan spesies tersebut pada medium kromogenik (ChromID). Selanjutnya dihitung sensitivitas dan spesifisitas medium kromogenik dalam identifikasi $E$. coli dan K. pneumoniae penghasil ESBL.

\section{Hasil Penelitian}

Dari total 343 spesimen urin, yang tumbuh pada medium MCA dan BA untuk selanjutnya diperiksa dengan Phoenix adalah 146 sampel, sedangkan yang tumbuh pada medium kromogenik dari total sampel adalah 98 sampel, dengan 69 sampel diantaranya menghasilkan koloni merah dan hijau.

Tabel 5.1. Distribusi data sampel berdasarkan asal ruangan

\begin{tabular}{lccccc}
\hline \multicolumn{1}{c}{ Asal sampel } & Anak & $\begin{array}{c}\text { Penyakit } \\
\text { Dalam }\end{array}$ & Bedah & Total \\
\hline Spesimen urin & 118 & 117 & 108 & 343 \\
\hline E. coli Phoenix & 11 & 24 & 12 & 47 \\
E. coli ESBL & 5 & 19 & 8 & 32 \\
\hline K. pn Phoenix & 11 & 8 & 4 & 23 \\
K. pn ESBL & 8 & 6 & 4 & 18 \\
\hline Phoenix ESBL & 13 & 25 & 12 & 50 \\
\hline ChromIDESBL & 20 & 33 & 16 & 69 \\
E. coli (merah) & 7 & 24 & 10 & 41 \\
KESC (hijau) & 13 & 9 & 6 & 28 \\
\hline
\end{tabular}

Berdasarkan tabel diatas dapat diketahui bahwa dari total sampel yang diidentifikasi sebagai $E$. coli dan $K$. pneumoniae dengan Phoenix sebanyak 70 sampel (47 E. coli dan 23 K. pneumoniae), didapatkan 50 sampel diantaranya adalah penghasil ESBL.

Tabel 5.2. Identifikasi E. coli penghasil ESBL pada medium kromogenik dibandingkan dengan Phoenix

\begin{tabular}{clcc}
\hline & & \multicolumn{2}{c}{$\begin{array}{c}\text { Identifikasi } \\
\text { Phoenix }\end{array}$} \\
\cline { 3 - 4 } & & E. coli & $\begin{array}{c}\text { Positif } \\
\text { ESBL }\end{array}$ \\
\hline Warna koloni & Merah & 34 & 31 \\
medium & Colorless & 4 & 0 \\
kromogenik & Non ESBL & 9 & 1 \\
\hline \multicolumn{2}{c}{ Total } & 47 & 32 \\
\hline
\end{tabular}

Dari tabel 5.2 dapat diketahui bahwa dari 47 sampel E. coli, hanya 34 diantaranya yang berwarna merah dengan medium kromogenik, dan 31 diantaranya terdeteksi sebagai penghasil ESBL. Didapatkan 4 
sampel E. coli yang tumbuh tidak berwarna pada medium kromogenik, tetapi non ESBL.

Penilaian sensitivitas dan spesifisitas medium kromogenik terhadap Phoenix, dapat dilihat pada tabel 5.3.

Tabel 5.3. Sensitivitas dan spesifisitas medium kromogenik pada $E$. coli terhadap Phoenix

\begin{tabular}{llccc}
\hline & & \multicolumn{2}{c}{ Phoenix } & \\
\cline { 3 - 4 } & & Positif & Negatif & Total \\
\hline Medium & Positif & 31 & 3 & 34 \\
kromogenik & Negatif & 1 & 12 & 13 \\
\hline \multicolumn{2}{c}{ Total } & 32 & 15 & 47 \\
\hline
\end{tabular}

Dari tabel 5.3 dapat dinilai sensitivitas, spesifisitas, Positive predictive value ( PPV) dan Negative predictive value (NPV) medium kromogenik (ChromID) dalam identifikasi $E$. coli yaitu masing-masing adalah $96,9 \%, 80 \%$, 91,2\%, dan 92,3 \%. Hasil uji Mc Nemar dan Kappa menunjukkan $\mathrm{P}>0,05$, sehingga terdapat kesesuaian atau tidak ada perbedaan hasil identifikasi antara medium kromogenik dengan Phoenix dalam identifikasi E. coli penghasil ESBL.

Tabel 5.4. Identifikasi K. pneumoniae penghasil ESBL pada medium kromogenik dibandingkan dengan Phoenix

\begin{tabular}{lccc}
\hline & & \multicolumn{2}{c}{ Identifikasi Phoenix } \\
\cline { 3 - 4 } & & K. pn & $\begin{array}{c}\text { Positif } \\
\text { ESBL }\end{array}$ \\
\hline Warna & Hijau & 18 & 18 \\
koloni & Non ESBL & 5 & 0 \\
ChromID & & \\
\hline \multicolumn{2}{c}{ Total } & 23 & 18 \\
\hline
\end{tabular}

Dari tabel 5.4 dapat diketahui bahwa dari 23 sampel yang diidentifikasi sebagai $K$. pneumoniae penghasil ESBL, 18 sampel diantaranya positif ESBL dan menghasilkan koloni berwarna hijau dengan medium kromogenik.
Tabel 5.5. Sensitivitas dan spesifisitas medium kromogenik pada $K$. pneumoniae penghasil ESBL terhadap Phoenix

\begin{tabular}{llccc}
\hline & & \multicolumn{2}{c}{ Phoenix } & \\
\cline { 3 - 4 } & & Positif & Negatif & Total \\
\hline Medium & Positif & 18 & 0 & 18 \\
kromogenik & Negatif & 0 & 5 & 5 \\
ESBL $K . p n$ & & & & \\
\hline \multicolumn{1}{c}{ Total } & 18 & 5 & 23 \\
\hline
\end{tabular}

Dari tabel 5.5 dapat diperoleh nilai sensitivitas, spesifisitas, PPV dan NPV medium kromogenik dalam identifikasi $K$. penumoniae penghasil ESBL yaitu sebesar $100 \%$.

Hasil uji Mc Nemar dan Kappa menunjukkan $\mathrm{P}=1$ atau $\mathrm{P}>0,05$ sehingga terdapat kesesuaian atau tidak ada perbedaan hasil identifikasi antara medium kromogenik dengan Phoenix dalam identifikasi K. pneumoniae penghasil ESBL.

Tabel 5.6. Hasil Identifikasi E. coli Dan K. pneumoniae Penghasil ESBL antara Medium Kromogenik dengan Phoenix

\begin{tabular}{ccccc}
\hline & & \multicolumn{2}{c}{ Phoenix } & Total \\
\cline { 3 - 4 } & & Pos & Neg & \\
\hline ChromID & Pos & 49 & 3 & 52 \\
ESBL & Neg & 1 & 17 & 18 \\
\hline \multicolumn{2}{c}{ Total } & 50 & 20 & 70 \\
\hline
\end{tabular}

Berdasarkan tabel 5.6 di atas, dapat dihitung nilai sensitivitas, spesifisitas, PPV dan NPV medium kromogenik dalam identifikasi $E$. coli dan K. pneumoniae penghasil ESBL masing-masing adalah 98\%, 85\%, 94,2 \% dan 94,4\%. Dilakukan perhitungan dengan menggunakan Mc Nemar dan Kappa, didapatkan hasil $\mathrm{P}>0,05$ sehingga dapat disimpulkan bahwa terdapat kesesuaian hasil atau tidak terdapat perbedaan hasil identifikasi E. coli dan K. pneumoniae penghasil ESBL antara medium kromogenik dengan Phoenix. 


\section{Pembahasan}

Berdasarkan hasil penelitian yang disajikan pada tabel 5.1 menunjukkan bahwa hasil pengumpulan sampel didapatkan total 344 sampel, 69 sampel terdeteksi sebagai penghasil ESBL pada medium kromogenik, 41 sampel diidentifikasi sebagai E. coli dengan koloni berwarna merah $(41,8 \%)$ dan 28 sampel diidentifikasi sebagai Klebsiella, Enterobacter, Serratia, Citrobacter (KESC) dengan koloni berwarna hijau (28,6\%), sedangkan 29 sampel lainnya diidentifikasi sebagai non fermenter dengan koloni tidak berwarna sampai kecoklatan. Hasil tersebut sesuai dengan yang dilakukan Wasito, 2013 yang menunjukkan angka kejadian ESBL pada spesimen urin di RSUD dr. Soetomo periode januari sampai oktober 2013 untuk E. coli adalah sebesar $42 \%$ dan K. pneumoniae sebesar $33 \%$. Sedangkan penelitian sebelumnya oleh Kuntaman, et al., tahun 2005 menunjukkan hasil proporsi ESBL pada spesimen klinis RSUD dr. Soetomo adalah sebesar $34.84 \%$ untuk Escherichia coli, dan 35.35 \% untuk Klebsiella pneumoniae. Sedangkan hasil penelitian Antimicrobial Resistance prevalence and prevention (AMRIN) menemukan bahwa kejadian ESBL cukup tinggi yakni $36 \%$ pada K. pneumoniae dan 29\% pada E. coli (Irawan, et al., 2012). Berdasarkan data tersebut diatas dapat dilihat adanya pergeseran spesies penghasil ESBL, pada penelitian tahun 2005, proporsi bakteri penghasil ESBL utama di RSUD dr. Soetomo adalah Klebsiella pneumoniae, sedangkan pada tahun 2013, persentase yang lebih tinggi ditunjukkan oleh Escherichia coli. Hasil E. coli sebagai penghasil ESBL terbanyak pada isolat klinis juga sesuai dengan penelitian Patterson, 2006 yang menyebutkan bahwa E. coli adalah penghasil ESBL yang paling dominan yang ditemukan di banyak negara di seluruh dunia.
Berdasarkan hasil pada Phoenix didapatkan total 47 sampel yang diidentifikasi sebagai E. coli dengan 32 sampel diantaranya adalah positif ESBL, sedangkan yang diidentifikasi positif berwarna merah pada medium kromogenik adalah 34 sampel, 4 sampel koloni E. coli tidak berwarna, dan terdapat 9 sampel $E$. coli tidak tumbuh pada medium kromogenik atau non ESBL, tetapi 1 sampel positif ESBL dengan Phoenix. Hal tersebut kemungkinan bisa disebabkan oleh adanya kesalahan dalam melakukan inokulasi pada medium kromogenik. Pada penelitian didapatkan 4 sampel E. coli yang tumbuh dengan tidak berwarna pada medium kromogenik. Hasil yang sama juga ditemukan pada penelitian Reglier, et al., 2008 adanya koloni E. coli yang tidak berwarna setelah inkubasi 24 jam, hal tersebut dapat disebabkan oleh adanya defisiensi dari ekspresi enzim $\beta$ glukoronidase pada isolat tersebut. Untuk dapat membedakan koloni E. coli yang tidak berwarna dengan bakteri nonfermenter lainnya dapat dilakukan tes oksidase untuk meningkatkan sensitivitas terhadap medium kromogenik (Gazin, et al., 2012).

Pada penelitian ini didapatkan sensitivitas dan spesifisitas medium kromogenik dalam deteksi dini E. coli penghasil ESBL masing-masing adalah 96,9 \% dan $80 \%$, sedangkan PPV dan NPV masing-masing adalah $91,2 \%$ dan $92,3 \%$. Hasil tersebut menunjukkan bahwa sensitivitas lebih tinggi dibandingkan spesifisitas medium kromogenik dalam deteksi E. coli, hal tersebut sesuai dengan hasil penelitian dari Farber, et al., 2008 dengan sensitivitas ChromID pada E. coli adalah $94,2 \%$ dan spesifisitas $42,9 \%$, sedangkan PPV dan NPV masing-masing adalah $94,2 \%$ dan $42,9 \%$.

Kesulitan utama dalam menggunakan medium skrining adalah dalam membedakan penghasil ESBL dengan isolat resisten lainnya yang berhubungan dengan mekanisme resistensi yang lain, terutama 
penghasil AmpC yang diperantarai oleh plasmid atau secara kromosomal. Enterobacter spp. dinilai yang paling sering menyebabkan false positives, termasuk pada ChromID (Reglier, et al., 2008).

Berdasarkan hasil Phoenix diidentifikasi 23 sampel sebagai K. pneumoniae, 18 diantaranya adalah positif ESBL. Tingginya angka positif ESBL dari spesies $K$. pneumoniae diatas berkaitan dengan tingginya angka infeksi nosokomial akibat Klebsiella dihubungkan dengan semakin banyaknya penggunaan antibiotik. Penggunanan terapi antimikroba secara luas bertanggungjawab terhadap berkembangnya strain Klebsiella resisten di rumah sakit, salah satunya adalah strain penghasil ESBL yang insidennya terus meningkat. Selain itu, emergensi dari berkembangnya strain Klebsiella resisten diikuti dengan adanya stabilitas yang relatif tinggi pada plasmid pengkode ESBLs (Podschun and Ullmann, 1998).

Hasil penelitian didapatkan nilai sensitivitas dan spesifisitas medium kromogenik dalam mendeteksi $K$. pneumoniae penghasil ESBL adalah 100\%, dengan PPV dan NPV sebesar 100\%. Hasil tersebut sesuai dengan penelitian yang dilakukan oleh Farber, et al., tahun 2008 yang membandingkan beberapa metode dalam deteksi ESBL (medium kromogenik, vitek dan phoenix) yaitu didapatkan hasil NPV, PPV, sensitifitas dan spesifisitas 100\% untuk medium kromogenik dan sistem otomatis.

Farber, et al., 2008 menyebutkan bahwa skrining isolat Enterobacteriaceae penghasil ESBL selain E. coli dan Klebsiella spp. tidak direkomendasikan oleh CLSI (Clinical and Laboratory Standards Institute). Masalah dalam deteksi penghasil ESBL terjadi khususnya pada Enterobacter spp., Serratia spp., dan Citrobacter spp. spesies ini dapat menghasilkan $\beta$-laktamase yang dapat dikode oleh AmpC yang menyebabkan tejadinya tumpang tindih fenotipe dari resistensi yang berbeda.

Hasil penelitian untuk sensitivitas dan spesifisitas medium kromogenik dalam deteksi dini E. coli dan K. pneumoniae penghasil ESBL yang dibandingkan dengan Phoenix, didapatkan sensitivitas sebesar 98\% dan spesifistitas 85\%, sedangkan PPV dan NPV masing-masing sebesar $94,2 \%$ dan 94,4\%. Hasil yang didapatkan pada penelitian Farber, et al., tahun 2008 menyebutkan bahwa hasil sensitivitas terhadap ChromID tinggi yaitu sebesar $95,6 \%$ sedangkan spesifisitasnya yaitu $23,4 \%$, PPV dan NPV masing-masing adalah 92,6\% dan 30,0\%. Hasil penelitian Overdest, et al., tahun 2011 menunjukkan sensitivitas ChromID sebesar 97,3\% dengan spesifisitas 93,9\%.

Dilakukan pengulangan Phoenix untuk 4 sampel dengan hasil identifikasi phoenix yang berbeda dengan warna koloni ESBL. sebanyak 2 sampel dengan koloni yang tidak berwarna pada medium kromogenik awalnya diidentifikasi Phoenix sebagai E. coli, hasil konfirmasi dengan DDST positif, sedangakan hasil pada Phoenix ulangan untuk kedua sampel tersebut menunjukkan hasil sebagai Acinetobacter, spp. Hal tersebut sesuai dengan penjelasan bahwa enzim ESBL selain ditemukan secara luas pada kelompok Enterobactericeae, juga ditemukan pada bakteri nonfermenter lainnya seperti Pseudomonas aeruginosa dan Capnocytophaga ochracea yang memiliki kemampuan yang sama dalam menghidrolisis golongan sefalosporin spektrum luas dan monobaktam, serta dapat dihambat oleh asam klavulanat (Rupp and Fey, 2003).

\section{Kesimpulan dan Saran}

Berdasarkan uraian di atas dapat disimpulkan bahwa penggunaaan medium kromogenik dapat digunakan dalam deteksi dini dan identifikasi E. coli penghasil ESBL pada spesimen urin yang memiliki sensitivitas yang tinggi yaitu $96,9 \%$ dan 
spesifisitas 80\%, sedangkan PPV dan NPV masing-masing adalah $91,2 \%$ dan $92,3 \%$. Penggunaaan medium kromogenik dapat digunakan dalam deteksi dini dan identifikasi K. pneumoniae penghasil ESBL pada spesimen urin dengan sensitivitas, spesifisitas, PPV dan NPV yang lebih tinggi yaitu sebesar $100 \%$.

Metode deteksi dini secara cepat dengan menggunakan medium kromogenik untuk mendeteksi Enterobactericeae penghasil ESBL khususnya E. coli dan $K$. pneumoniae dapat dilakukan pada pelayanan klinis, terutama pada kondisi terjadinya wabah, skrining pasien yang akan dipindahkan ke rumah sakit lain yang secara umum memiliki insiden ESBL yang tinggi, juga untuk memonitor status carrier ESBL pada pasien. Penggunaan medium kromogenik sebagai medium skrining yang mudah dan cepat serta biaya yang lebih terjangkau diharapkan dapat menjadi solusi dalam deteksi dini dan identifikasi penghasil ESBL terutama di Rumah Sakit dengan fasilitas laboratorium yang belum memiliki metode otomatis seperti Phoenix.

\section{Daftar Pustaka}

1. Bradford PA, 2001. Extended-spectrumlactamases in the 21st century: characterization, epidemiology, and detection of this important resistance threat. Clin. Microbiol. Rev. 2001:14:933951.

2. Colodner R, Raz R. 2005. ExtendedSpectrum Beta-Lactamases : The End of Cephalosporins? IMAJ 2005 :7:336.

3. Coque, TM, Baquero F and Cantoni R. 2008. Increasing prevalence of ESBL producing Enterobactericeae in Europe. Eurosurveillance 2008:13(47):1-7.

4. Farber J, KA Moder, F Layer, I Tammer, W Konig and B. Konig. 2008. ExtendedSpectrum Beta-Lactamase Detection with Different Panels for Automated Susceptibility Testing and with a
Chromogenic Medium. Journal Of Clinical Microbiology, American Society for Microbiology 2008 :46:(11):3721-3727.

5. Gazin Muriel, Fabienne Paasch, Herman Goossens, and Surbhi Malhotra-Kumar. 2012. Current Trends in Culture-Based and Molecular Detection of ExtendedSpectrum- $\beta$ Lactamase-Harboring and Carbapenem-Resistant

Enterobacteriaceae J. Clin. Microbiology 2012:50:(4):1140-1142.

6. Glupczynski Youri, Catherine Berhin, Caroline Bauraing, Pierre Bogaerts. 2006. Evaluation of a New Selective Chromogenic Agar Medium for Detection of Extended-Spectrum $\beta$ Lactamase-Producing

Enterobacteriaceae. Journal Of Clinical Microbiology 2006:45:(2):501-504.

7. Huang Te-Din, Pierre Bogaerts, Catherine Berhin, Amelie Guisset,Youri Glupczynski. 2010. Evaluation of Brilliance ESBL Agar, a Novel Chromogenic Medium for Detection of Extended-Spectrum-Beta- LactamaseProducing Enterobacteriaceae. Journal Of Clinical Microbiology 2010:48 (6):2091-2096.

8. Irawan Danny, Hamidah, Purwati, Triyono EA, Bramantono, Arfianto V, Hadi U, Nasronudin, Suharto, Soewandojo E. 2012. Profil Penderita Sepsis Akibat Bakteri Penghasil ESBL. J Peny Dalam 2012:13(1):63.

9. Kluytmans-Vandenberg, MFQ, JAJW Kluytmans and A Vos. 2005. Dutch guideline for preventing nosocomial transmission of highly resistant microorganisms (HRMO) Infection 2005:33:309-313.

10. Kuntaman, Mertaniasih NM, Purwanta M. Dalam: Usman Hadi, Nasronudin. 2005. Bakteri penghasil ESBL dari spesimen klinik di RSU dr Soetomo Surabaya. Simposium penyakit infeksi dan problema resistensi antimikroba. Surabaya: FK Unair, hlm 1-9. 
11. Kuntaman, Sanarto S, Hendro W, Ni Made M. 2011. The Sensitivity Pattern of Extended Spectrum Beta LactmaseProducing Bacteria Against Six Antibiotics that Routinely Used in Clinical Setting. Journal of the Indonesian Medical Association (Majalah Kedokteran Indonesia) 2011:61(12) :482-486.

12. Lucet JC, D Decre, A Fichelle, ML JolyGuillou, M Pernet, C Deblangy, MJ Kosmann and B Regnier. 1999. Control of a prolonged outbreak of extendedspectrum beta-lactamase-producing Enterobacteriaceae in a university hospital. Clin. Infect. Dis. 1999: 29 :14111418.

13. Mark E. Rupp and Paul D Fey, 2003. Extended Spectrum $\beta$-Lactamase (ESBL)-Producing Enterobacteriaceae Considerations for Diagnosis, Prevention and Drug Treatment. Drugs, 63(4):354.

14. Meyer E, A Serr, C Schneider, S Utzolino, WV Kern, R Scholz and M. Dettenkofer, 2009. Should we screen patients for extended-spectrum betalactamaseproducing Enterobacteriaceae in intensive care units? Infect. Control Hosp. Epidemiology 2009: 30:103-105.

15. Overdest ITMA, Willemsen, S Elberts, C Verhulst and JAJW Kluytmans. 2011. Laboratory Detection of ExtendedSpectrum-Beta-Lactamase-Producing Enterobacteriaceae: Evaluation of Two Screening Agar Plates and Two Confirmation Techniques. Journal Of Clinical Microbiology 2011: 49(2):519522.

16. Paterson DL and Bonomo RA, 2005. Extended-spectrum b-Lactamases: a Clinical Update. Clin Microbiol Review 2005:18:658-672.

17. Perry JD and AM Freydie're. 2007. The application of chromogenic media in clinical. Journal of Applied
Microbiology Review 2007:103:20462055.

18. Pitout Johann D and Kevin B Laupland. 2008. Extended-spectrum $\beta$-lactamaseproducing Enterobacteriaceae: an emerging public-health concern. Lancet Infect Diseases 2008: 8:159-161.

19. Pfaller Michael A and John Segreti. 2006. Overview of the Epidemiological Profile and Laboratory Detection of ExtendedSpectrum beta-Lactamases. Clinical Infectious Diseases 2006:42:154-159.

20. Poupet Helene Reglier, Thierry Naas, Amelie C, Anne C, Jean-Marie A, Nicolas F, Claire P and Patrice N. 2008. Performance of chromID ESBL, a chromogenic medium for detection of Enterobacteriaceae producing extendedspectrum beta lactamases. Journal of Medical Microbiology 2008:57:310-315.

21. Podschun R and U Ullmann. 1998. Clinical Microbiology Reviews, Klebsiella spp. as Nosocomial Pathogens: Epidemiology, Taxonomy, Typing Methods, and Pathogenicity Factors. American Society for Microbiology 1998:11:(4) :589-603.

22. Reddy P, M Malczynski, A Obias, S Reiner, N Jin, J Huang, GA Noskin and $\mathrm{T}$ Zembower. 2007. Screening for extended-spectrum betalactamaseproducing Enterobacteriaceae among high-risk patients and rates of subsequent bacteremia. Clin. Infect. Diseases 2007:45:846-852.

23. Schwaber MJ and Y Carmeli. 2007. Mortality and delay in effective therapy associated with extended-spectrum lactamase production in Enterobacteriaceae bacteraemia: a systemic review and meta-analysis. J. Antimicrob. Chemother 2007: 60:913920.

24. Tsang DNC, Que TL, Ho M, Yuen KY. 2000. Comparison of screening methods for detection of extended-spectrum $\beta$ Lactamases and their prevalens among 
Escherichia coli and Klebsiella species in Hongkong. APMIS 2000 :108:237-40.

25. Wasito EB. 2013. Laporan Prevalensi ESBL Januari-Oktober 2013 di RSUD dr. Soetomo, Surabaya.

26. Wiegand Irith, Heinrich KG, Dietrich Mack, Enno Stu"renburg and Harald S. 2007. Detection of Extended-Spectrum Beta-Lactamases among Enterobacteriaceae by Use of Semiautomated Microbiology Systems and Manual Detection Procedures. Journal Of Clinical Microbiology 2007 :45(4):1167-1174.
27. Wong A and Beringer. 2001. Theurapetic Challenges Associated with Extended Spectrum Beta Laktamase Producing E. coli and K. pneumoniae. J pharmacotherapy $2001: 21(5): 583-59$. 